\title{
SELECTIVITY OF SAFLUFENACIL APPLIED SINGLY AND IN COMBINATION WITH GLYPHOSATE ON COFFEE AND CITRUS CROPS ${ }^{1}$
}

\author{
CLEBSON GOMES GONÇALVES ${ }^{2 *}$, ANTONIO CARLOS DA SILVA JUNIOR ${ }^{2}$, MARIA RENATA ROCHA \\ PEREIRA $^{3}$, SIDNEI ROBERTO MARCHI ${ }^{4}$, DAGOBERTO MARTINS ${ }^{2}$
}

\begin{abstract}
Saflufenacil is absorbed by the plant leaves and roots, thus the residual permanence of this herbicide can cause losses to the crop plants. Therefore, the objective of this study was to evaluate the selectivity of the saflufenacil herbicide, applied singly and in combination with glyphosate, on coffee and citrus plants grown in a sandy soil. Two experiments were implemented and conducted in completely randomized design with four replications. The chemical treatments consisted of three sequential applications, with directed spraying of saflufenacil at rates of $0.035,0.07$ and $0.105 \mathrm{~kg}$ a.i. ha ${ }^{-1}$, glyphosate at rate of $2.160 \mathrm{~kg}$ a.e. ha ${ }^{-1}$, the two herbicides combined at the same rates, and a control without chemical treatment. The saflufenacil applied singly and in combination with glyphosate was selective for coffee and citrus plants, which presented no visual toxicity symptoms. The sequential application of saflufenacil, singly and in combination with glyphosate did not affect the growth of coffee and citrus plants. The saflufenacil has potential for use, in combination with glyphosate on controlling many weed species in coffee and citrus areas without any interference on the development of these species.
\end{abstract}

Keywords: Development. Directed spraying. Herbicide. Phytotoxicity.

\section{SELETIVIDADE DO SAFLUFENACIL ISOLADO E EM ASSOCIAÇÃO COM GLYPHOSATE EM CULTURAS DE CAFÉ E CITROS}

RESUMO - O saflufenacil é absorvido pelas folhas e raízes das plantas, por isso a permanência residual deste herbicida pode provocar prejuízos para as plantas cultivadas. Portanto, este trabalho teve como objetivo avaliar a seletividade do herbicida saflufenacil aplicado isolado e em associação com glyphosate, em plantas de café e citros cultivadas em solo arenoso. Foram instalados e conduzidos dois experimentos no delineamento inteiramente casualizado, com quatro repetições. Os tratamentos químicos consistiram de três aplicações sequenciais, com jato dirigido de saflufenacil nas doses de $0,035,0,07$ e 0,105 kg i.a. ha ${ }^{-1}$, de glyphosate na dose de 2,160 kg e.a. ha ${ }^{-1}$, e da associação dos dois herbicidas nas mesmas doses, além de uma testemunha sem tratamento químico. O saflufenacil aplicado isolado e em associação com glyphosate foi seletivo para plantas de café e citros, não apresentando nenhum sintoma visual de intoxicação nas plantas. A pulverização sequencial de saflufenacil isolada e em associação com glyphosate não afetou o crescimento das plantas de café e citros. O saflufenacil tem um potencial de uso em associação com glyphosate para fornecer controle de muitas espécies de plantas daninhas em áreas de café e citros sem nenhuma interferência no desenvolvimento destas espécies.

Palavras-chave: Desenvolvimento. Jato dirigido. Herbicida. Fitointoxicação.

\footnotetext{
*Corresponding Author

${ }^{1}$ Received for publication in $02 / 06 / 2015$; accepted in $12 / 21 / 2015$.

Paper extracted from the research interest of Department of Crop Production FCA/UNESP, Botucatu/SP

${ }^{2}$ Departament of Crop Production, Faculdade de Ciências Agrárias e Veterinárias, Universidade Estadual Paulista, Jaboticabal, SP, Brazil; goncalvescg.agro@hotmail.com, acsjr_agro@hotmail.com,dmartins@fcav.unesp.br.

${ }^{3}$ Faculdade de Tecnologia de Capão Bonito, Capão Bonito, SP, Brazil; mariarenatarp@hotmail.com.

${ }^{4}$ Institute of Exact Sciences and Earth, Universidade Federal de Mato Grosso, Barra do Garças, MT, Brazil; sidneimarchi.ufmt@gmail.com.
} 


\section{INTRODUCTION}

The presence of weeds is one of the most important factors that affect the growth, development and productivity of plants in areas covered with perennial crops. The main strategies for weed management in areas with citrus and coffee crops are conducted through integrated systems with herbicide application, such as glyphosate, applied at postemergence with directed spraying at planting and mowing between rows.

Glyposate is among the most recommended herbicides for controlling annual and perennial weeds because it is a non-selective herbicide with broad action. However, the strong dependence on glyphosate in croplands has resulted in loss of its effectiveness in weeds, that became tolerant to this herbicide due to selection pressure (MOREIRA et al., 2007; OWEN, 2008; POWLES, 2008; YAMAUTI et al., 2010). Thus, the combination of herbicides with different mechanisms of action may be a viable alternative to ensure the success in weed managements.

The saflufenacil herbicide is an inhibitor of the enzyme protoporphyrinogen IX oxidase (PPO or PROTOX), it is used at post-emergence for controlling a broad range of eudicotyledonous weeds and has potential for use in combination with glyphosate (GROSSMANN et al., 2010). Martins et al. (2012) showed that the combination of saflufenacil with glyphosate provided satisfactory control of Commelina benghalensis and Commelina villosa plants.

The saflufenacil action and destination in the soil must to be better studied, because it is absorbed by the plant roots, shoots and leaves (ASHIGH; HALL, 2010; GROSSMANN et al., 2011), and once in the soil, the herbicides may undergo sorption, leaching and degradation processes by physical, chemical and biological actions, and be absorbed by roots of crop plants, reducing their growth (FILIZOLA et al., 2002; SILVA et al., 2012).

Monquero et al. (2012) showed that the saflufenacil presented high leaching in two Latosols (Oxisols) with different textures, which was more pronounced in the sandy texture. Saflufenacil is a moderated acid, which has $\mathrm{pKa}$ of 4.3. Low sorption of this herbicide in soils with clayey and medium texture has been observed. A positive correlation has been observed between the saflufenacil sorption and the increase in organic carbon content in the soil (PAPIERNIK et al., 2012; MATALLO et al., 2014).

Glyphosate has a high adsorption capacity in the soil (CHEAH et al., 1997), on the other hand, studies suggest that the saflufenacil in the root zone is readily available in the soil solution for leaching, degradation or plant uptake (MONQUERO et al., 2012; PAPIERNIK et al., 2012; MATALLO et al., 2014).

The residual persistence of herbicides in soil has relevance for weed control, however, it can cause major losses to non-tolerant crop plants, especially when used in sequential applications. Thus, the action of these products on the weeds and crops must be take into account when applying more than one herbicide. Therefore, the objective of this work was to evaluate the selectivity of the saflufenacil herbicide applied singly and in combination with glyphosate using the directed spraying application mode, in coffee and citrus plants grown in a sandy soil.

\section{MATERIAL AND METHODS}

Two studies were conducted in the NuPAM (Center of Advanced Studies on Weed Science), from the FCA/UNESP, Botucatu campus, between July 2012 and June 2013, in pots with capacity of 60.0 L. The Catuai coffee variety and a Valencia citrus clone were used. The substrate used in the study consisted of a soil classified as Latosol (Oxisol) with the following physical characteristics: sand $=63 \%$, silt $=4.0 \%$ and clay $=33.0 \%$. The soil $\mathrm{pH}$ correction and fertility improvement were performed according to the recommendations for each crop (RAIJ et al., 1996). The initial soil chemical characteristics are shown in Table 1, and the chemical characteristics after corrections are shown in Table 2. After the fertilizer and amendment applications, the soils were wet, covered with plastic and left incubating for seventeen days before the seedling transplants.

Table 1. Initial chemical characteristics of the soil used in the study. Botucatu, SP, 2012/13.

\begin{tabular}{|c|c|c|c|c|c|c|c|c|c|}
\hline $\begin{array}{c}\mathrm{pH} \\
\mathrm{CaCl}_{2} \\
\end{array}$ & $\begin{array}{l}\text { M.O. } \\
\mathrm{g} \mathrm{dm}^{-3} \\
\end{array}$ & $\begin{array}{l}\text { P resin } \\
\mathrm{g} \mathrm{dm}^{-3} \\
\end{array}$ & $\begin{array}{r}\mathrm{H}+\mathrm{Al} \\
-\end{array}$ & $\begin{array}{c}\mathrm{K} \\
\mathrm{nmo} \\
\end{array}$ & $\begin{array}{c}\mathrm{Ca} \\
-3\end{array}$ & $\mathrm{Mg}$ & SB & $\mathrm{CTC}$ & $\mathrm{V} \%$ \\
\hline 4.1 & 22 & 2 & 56 & 0.2 & 2 & 1 & 3 & 60 & 6 \\
\hline \multicolumn{2}{|c|}{ BORON } & \multicolumn{2}{|c|}{ COPPER } & \multicolumn{2}{|c|}{ IRON } & \multicolumn{2}{|c|}{ MANGANESE } & \multicolumn{2}{|c|}{ ZINC } \\
\hline \multicolumn{2}{|c|}{0.12} & \multicolumn{2}{|c|}{0.9} & & & \multicolumn{2}{|c|}{0.2} & \multicolumn{2}{|c|}{0.1} \\
\hline
\end{tabular}


Table 2. Chemical characteristics of the soil used in the study after pH correction and fertility improvement. Botucatu, SP, 2012/13.

\begin{tabular}{|c|c|c|c|c|c|c|c|c|c|c|}
\hline & $\begin{array}{c}\mathrm{pH} \\
\mathrm{CaCl}_{2} \\
\end{array}$ & $\begin{array}{l}\text { M.O. } \\
\mathrm{g} \mathrm{dm}^{-3}\end{array}$ & $\begin{array}{l}\text { P resin } \\
\mathrm{g} \mathrm{dm}^{-3}\end{array}$ & $\mathrm{H}+\mathrm{Al}$ & $\begin{array}{c}\mathrm{K} \\
\mathrm{mmo} \\
\end{array}$ & $\begin{array}{r}\mathrm{Ca} \\
\mathrm{dm}^{-3}-\end{array}$ & $\mathrm{Mg}$ & SB & $\mathrm{CTC}$ & $\mathrm{V} \%$ \\
\hline Coffee & 5.2 & 22 & 93 & 34 & 1.5 & 39 & 9 & 49 & 83 & 59 \\
\hline Citrus & 5.4 & 23 & 89 & 31 & 1.5 & 40 & 10 & 52 & 82 & 63 \\
\hline & \multicolumn{2}{|c|}{ BORON } & \multicolumn{2}{|c|}{ COPPER } & \multicolumn{2}{|c|}{ IRON } & \multicolumn{2}{|c|}{ MANGANESE } & \multicolumn{2}{|c|}{ ZINC } \\
\hline Coffee & \multicolumn{2}{|c|}{0.58} & \multicolumn{2}{|c|}{0.9} & \multicolumn{2}{|c|}{45} & \multicolumn{2}{|c|}{1.5} & \multicolumn{2}{|c|}{1.2} \\
\hline Citrus & \multicolumn{2}{|c|}{0.5} & \multicolumn{2}{|c|}{0.9} & \multicolumn{2}{|c|}{47} & \multicolumn{2}{|c|}{1.1} & \multicolumn{2}{|c|}{0.9} \\
\hline
\end{tabular}

A topdressing fertilization with urea $(5.34 \mathrm{~g}$ per pot) and potassium chloride (4.97 g per pot) was performed fifteen days after the coffee and citrus seedling transplanting. A foliar fertilization was performed sixty days after seedling transplanting according to the Bulletin 100 of the Agronomic Institute of Campinas on both crops (RAIJ et al., 1996).

Both experiments were implemented and conducted in a completely randomized design with four replications. The chemical treatments studied consisted of saflufenacil (Heat/BASF) applied singly at rates of $0.035,0.07$ and $0.105 \mathrm{~kg}$ a.i. ha ${ }^{-1}$, glyphosate (Roundup WG/Monsanto) applied singly at rate of $2.160 \mathrm{~kg}$ a.e. $\mathrm{ha}^{-1}$, and the saflufenacil combined with glyphosate at the same rates, totaling 7 chemical treatments, and a control without herbicide. The Dash adjuvant was added $\left(0.5 \% \mathrm{v} \mathrm{v}^{-1}\right)$ to the treatments with saflufenacil applied singly and in combination with glyphosate, following the manufacturer's recommendations to maximize the saflufenacil effects on weed control.

The chemical treatments consisted of three sequential applications, using directed spraying with a 90 day-interval after the first application $(0,90$ and 180 days). The first herbicide application was performed 30 days after the seedling transplanting to the pots, in order to provide to the plants an adaptation time to the new conditions.

The herbicide applications were performed with a backpack sprayer with constant pressure by $\mathrm{CO}_{2}$, calibrated for a solution flow of $200 \mathrm{~L} \mathrm{ha}^{-1}$. The sprayer bar was equipped with two flat type nozzles (Teejet XR 11002VS) spaced $50 \mathrm{~cm}$ apart. The spraying was performed with the spray boom at a height of $0.5 \mathrm{~m}$ from the plant canopy.

The herbicides were applied directly to the ground without contact with the plants, which were protected during all applications with plastic bags, simulating a directed spraying application (Figure 1A; Figure 1B; Figure 1C; Figure 1D). After the herbicides application, $10 \mathrm{~mm}$ of rain was simulated on the pots to allow a greater availability of the herbicide in the soil solution of the root zone. The pots were watered as needed, always remaining under field conditions throughout the experimental period.

Visual evaluations of plant phytotoxicity were performed at 15, 30, 60, 90, 105, 120, 150, 180 and 195 days after the first application (DAA) of the chemical treatments, using a graded scale, in which 0 (zero) corresponded to no harm presented in the plant and 100 (one hundred) to the death of the plant, according to the Brazilian Society of Weed Science (SBCPD, 1995). The leaf number were counted and the plant height were measured, allowing to calculate the increase in leaf number and plant height in each study period.

The results of the increases in leaf number and plant height obtained were transformed according to the equation $\mathrm{y}=(\mathrm{x}+0.5)^{2}$ and subjected to analysis of variance by the $\mathrm{F}$ test and treatment averages were compared by the Tukey test $(\mathrm{p}<0.05)$. 

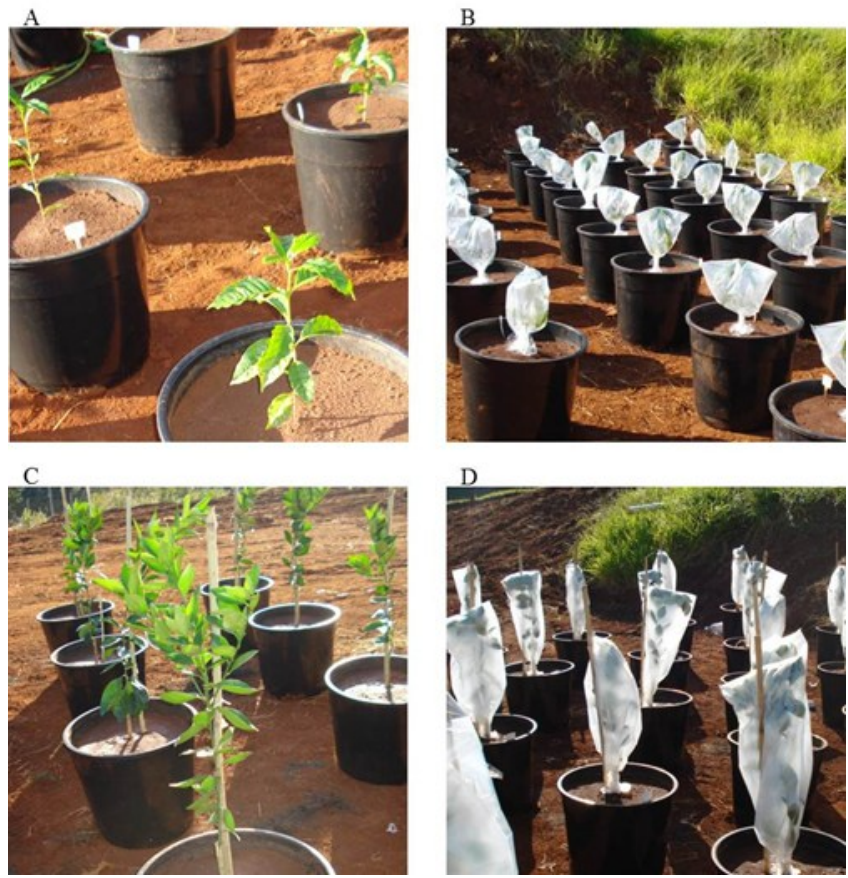

Figure 1. Coffee (A) and orange (C) plants at the first application of the chemical treatments; coffee (B) and orange (D) plants covered with plastic bags, prepared for receiving the first application of chemical treatments. Botucatu, SP, 2012/13.

\section{RESULTS AND DISCUSSION}

Papiernik et al. (2012); Matallo et al. (2014) reported that saflufenacil has a low sorption coefficient in medium textured soils, thus, it may be available in the root zone for uptake by plants. Therefore, a sandy soil was used in this study to ensure that the herbicide became available in the root zone for uptake by the plants.

Phytotoxicity evaluations were performed throughout the study on the Catuai coffee plants, and no visual symptoms due to the treatments were observed. The saflufenacil applied singly, as well as in combination with glyphosate, at the rates and application conditions studied were visually safe for use in the coffee crop (data not shown because all phytotoxicity scores were equal to zero) (Figure 2A; Figure 2B).

The saflufenacil applied singly or in combination with glyphosate showed no negative influence on the increase in height of the coffee plants, regardless of the rates. These results were also observed for the successive sprays performed at 90 and 180 DAA (Table 3).
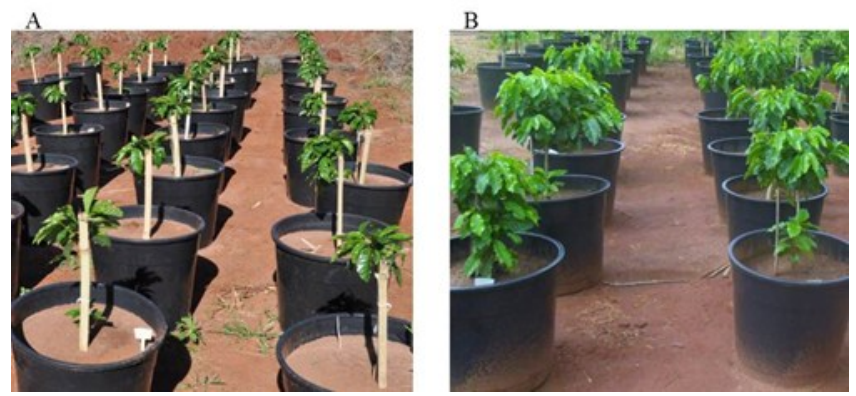

Figure 2. Coffee plants 90 days after the first application of chemical treatments (A) and after 195 days (B) at the end of the experimental period. Botucatu, SP, 2012/13.

These results corroborate the results found by Zambon et al. (2009), who evaluated the saflufenacil efficiency and selectivity in combination with glyphosate respectively at rates of $24.5+1.188$, $35.0+1.188$ and $49.0+1.188 \mathrm{~g}$ a.i. $\mathrm{ha}^{-1}$ sprayed at post -emergence between the coffee plant rows, and noted that all studied rates promoted excellent control levels for the major weeds present in the area without any phytotoxicity symptoms in the crop. 
C. G. GONÇALVES et al.

Table 3. Increase in height $(\mathrm{cm})$ of Catuai coffee plants subject to different herbicide applications. Botucatu, SP, 2012/13

\begin{tabular}{|c|c|c|c|c|c|c|c|c|c|c|}
\hline \multirow{2}{*}{ Treatments } & \multirow{2}{*}{$\begin{array}{c}\text { Rate } \\
\text { a.i./a.e. } \\
\left(\mathrm{Kg} \mathrm{ha}^{-1}\right)^{2}\end{array}$} & \multicolumn{9}{|c|}{ Evaluations } \\
\hline & & $\begin{array}{c}15 \\
\text { DAA } \\
\end{array}$ & $\begin{array}{c}30 \\
\text { DAA } \\
\end{array}$ & $\begin{array}{c}60 \\
\text { DAA } \\
\end{array}$ & $\begin{array}{c}90 \\
\mathrm{DAA}^{3}\end{array}$ & $\begin{array}{c}105 \\
\text { DAA } \\
\end{array}$ & $\begin{array}{c}120 \\
\text { DAA } \\
\end{array}$ & $\begin{array}{c}150 \\
\text { DAA } \\
\end{array}$ & $\begin{array}{c}180 \\
\mathrm{DAA}^{4} \\
\end{array}$ & $\begin{array}{c}195 \\
\text { DAA } \\
\end{array}$ \\
\hline Control & -- & $\begin{array}{c}1,50 \\
(1,38)\end{array}$ & $\begin{array}{c}0,50 \\
(1,21)\end{array}$ & $\begin{array}{c}0,25 \\
(1,15)\end{array}$ & $\begin{array}{c}4,25 \\
(1,64)\end{array}$ & $\begin{array}{c}0,75 \\
(1,23)\end{array}$ & $\begin{array}{c}1,75 \\
(1,37)\end{array}$ & $\begin{array}{c}1,00 \\
(1,31)\end{array}$ & $\begin{array}{c}5,00 \\
(1,65)\end{array}$ & $\begin{array}{c}2,00 \\
(1,43)\end{array}$ \\
\hline saflufenacil $^{1}$ & 0,035 & $\begin{array}{c}2,75 \\
(1,51)\end{array}$ & $\begin{array}{c}0,50 \\
(1,21)\end{array}$ & $\begin{array}{c}0,50 \\
(1,21)\end{array}$ & $\begin{array}{c}5,00 \\
(1,69)\end{array}$ & $\begin{array}{c}0,50 \\
(1,21)\end{array}$ & $\begin{array}{c}1,75 \\
(1,37)\end{array}$ & $\begin{array}{c}1,00 \\
(1,29)\end{array}$ & $\begin{array}{c}6,25 \\
(1,75)\end{array}$ & $\begin{array}{c}2,25 \\
(1,46)\end{array}$ \\
\hline saflufenacil $^{1}$ & 0,07 & $\begin{array}{c}3,00 \\
(1,53)\end{array}$ & $\begin{array}{c}0,00 \\
(1,10)\end{array}$ & $\begin{array}{c}0,50 \\
(1,21)\end{array}$ & $\begin{array}{c}4,25 \\
(1,61)\end{array}$ & $\begin{array}{c}1,00 \\
(1,31)\end{array}$ & $\begin{array}{c}2,75 \\
(1,52)\end{array}$ & $\begin{array}{c}1,25 \\
(1,34)\end{array}$ & $\begin{array}{c}6,00 \\
(1,70)\end{array}$ & $\begin{array}{c}2,00 \\
(1,43)\end{array}$ \\
\hline saflufenacil $^{1}$ & 0,105 & $\begin{array}{c}2,00 \\
(1,42)\end{array}$ & $\begin{array}{c}1,00 \\
(1,29)\end{array}$ & $\begin{array}{c}0,25 \\
(1,15)\end{array}$ & $\begin{array}{c}3,25 \\
(1,55)\end{array}$ & $\begin{array}{c}0,50 \\
(1.21)\end{array}$ & $\begin{array}{c}1,25 \\
(1,34)\end{array}$ & $\begin{array}{c}0,75 \\
(1,31)\end{array}$ & $\begin{array}{c}4,75 \\
(1,59)\end{array}$ & $\begin{array}{c}2,50 \\
(1,49)\end{array}$ \\
\hline saflu. + gly. ${ }^{1}$ & $0,035+2,160$ & $\begin{array}{c}2,00 \\
(1,42)\end{array}$ & $\begin{array}{c}0,50 \\
(1,21)\end{array}$ & $\begin{array}{c}0,75 \\
(1,24)\end{array}$ & $\begin{array}{c}3,75 \\
(1,59)\end{array}$ & $\begin{array}{c}2,50 \\
(1,46)\end{array}$ & $\begin{array}{c}5,00 \\
(1,67)\end{array}$ & $\begin{array}{c}3,00 \\
(1,53)\end{array}$ & $\begin{array}{c}4,00 \\
(1,57)\end{array}$ & $\begin{array}{c}1,75 \\
(1,40)\end{array}$ \\
\hline saflu. + gly. ${ }^{1}$ & $0,07+2,160$ & $\begin{array}{c}1,50 \\
(1,35)\end{array}$ & $\begin{array}{c}1,75 \\
(1,37)\end{array}$ & $\begin{array}{c}1,25 \\
(1,34)\end{array}$ & $\begin{array}{c}3,25 \\
(1,62)\end{array}$ & $\begin{array}{c}1,25 \\
(1,32)\end{array}$ & $\begin{array}{c}2,00 \\
(1,42)\end{array}$ & $\begin{array}{c}3,25 \\
(1,48)\end{array}$ & $\begin{array}{c}7,25 \\
(1,80)\end{array}$ & $\begin{array}{c}3,15 \\
(1,55)\end{array}$ \\
\hline saflu. + gly. ${ }^{1}$ & $0,105+2,160$ & $\begin{array}{c}2,00 \\
(1,42)\end{array}$ & $\begin{array}{c}0,25 \\
(1,15)\end{array}$ & $\begin{array}{c}0,75 \\
(1,24)\end{array}$ & $\begin{array}{c}4,25 \\
(1,62)\end{array}$ & $\begin{array}{c}2,00 \\
(1,42)\end{array}$ & $\begin{array}{c}4,00 \\
(1,54)\end{array}$ & $\begin{array}{c}3,25 \\
(1,56)\end{array}$ & $\begin{array}{c}5,25 \\
(1,57)\end{array}$ & $\begin{array}{c}3,00 \\
(1,53)\end{array}$ \\
\hline glyphosate & 2,16 & $\begin{array}{c}2,50 \\
(1,48)\end{array}$ & $\begin{array}{r}0,25 \\
-(1,15)\end{array}$ & $\begin{array}{c}1,00 \\
(1,27)\end{array}$ & $\begin{array}{c}3,50 \\
(1,58)\end{array}$ & $\begin{array}{c}1,25 \\
(1,34)\end{array}$ & $\begin{array}{c}2,50 \\
(1,48)\end{array}$ & $\begin{array}{c}1,25 \\
(1,34)\end{array}$ & $\begin{array}{c}5,50 \\
(1,72)\end{array}$ & $\begin{array}{c}1,75 \\
(1,41) .\end{array}$ \\
\hline $\mathrm{F}_{\text {TREATMENT }}$ & & $1,010^{\mathrm{ns}}$ & $1,707^{\mathrm{ns}}$ & $0,835^{\mathrm{ns}}$ & $0,575^{\mathrm{ns}}$ & $1,509^{\mathrm{ns}}$ & $1,483^{\mathrm{ns}}$ & $2,359^{\text {ns }}$ & $0,471^{\mathrm{ns}}$ & $1,425^{\text {ns }}$ \\
\hline C.V. $(\%)$ & & 8,72 & 10,7 & 11,2 & 7,4 & 11,4 & 11,7 & 10 & 15,4 & 6,4 \\
\hline d.m.s. & & 0,29 & 0,3 & 0,32 & 0,28 & 0,35 & 0,4 & 0,33 & 0,6 & 0,22 \\
\hline
\end{tabular}

The data processed according to the equation $\mathrm{y}=(\mathrm{x}+0.5)^{\wedge} 2$ are shown within parentheses. ${ }^{1}$ The adjuvant Dash was added at $0.5 \% \mathrm{v} \mathrm{v}^{-1} ;{ }^{2}$ a.i. $=$ active ingredient; e.a. $=$ acid equivalent; ${ }^{3}$ second application; ${ }^{4}$ third application; DAA $=$ days after first application; saflu. $=$ Saflufenacil; gly. $=$ Glyphosate; ${ }^{\text {ns }}=$ not significant.

Regarding the increase in leaf number of coffee plants, there was loss of leaves in most treatments in the first evaluation (15 DAA), except for the treatment which received saflufenacil $\left(0.105 \mathrm{~kg}\right.$ a.i. $\left.\mathrm{ha}^{-1}\right)$ combined with glyphosate $\left(2.160 \mathrm{~kg}\right.$ a.e. $\left.\mathrm{ha}^{-1}\right)($ Table 4). However, this probably happened because the coffee seedlings were still adapting to the new conditions in the pots after transplanting, since no significant difference was observed in the evaluations conducted at 30,60 and 90 DAA that could be attributed to the application of chemical treatments (Table 4).

Table 4. Increase in leaf number of Catuai coffee plants submitted to different herbicide applications. Botucatu, SP, 2012/13

\begin{tabular}{|c|c|c|c|c|c|c|c|c|c|c|}
\hline \multirow[b]{2}{*}{ Treatments } & \multirow{2}{*}{$\begin{array}{c}\text { Rate } \\
\text { a.i./a.e. } \\
\left(\mathrm{Kg} \mathrm{ha}^{-1}\right)^{2}\end{array}$} & \multicolumn{9}{|c|}{ Evaluations } \\
\hline & & $\begin{array}{c}15 \\
\text { DAA }\end{array}$ & $\begin{array}{c}30 \\
\text { DAA }\end{array}$ & $\begin{array}{c}60 \\
\text { DAA }\end{array}$ & $\begin{array}{c}90 \\
\mathrm{DAA}^{3}\end{array}$ & $\begin{array}{c}105 \\
\text { DAA }\end{array}$ & $\begin{array}{c}120 \\
\text { DAA }\end{array}$ & $\begin{array}{c}150 \\
\text { DAA }\end{array}$ & $\begin{array}{c}180 \\
\text { DAA }^{4}\end{array}$ & $\begin{array}{c}195 \\
\text { DAA } \\
\end{array}$ \\
\hline Control & -- & $-0,25$ & $\begin{array}{c}6,75 \\
(2,56)\end{array}$ & $\begin{array}{l}10,00 \\
(3,2)\end{array}$ & $\begin{array}{l}40,75 \\
(6,36)\end{array}$ & $\begin{array}{l}11,50 \\
(3,47)\end{array}$ & $\begin{array}{l}22,75 \\
(4,82)\end{array}$ & $\begin{array}{l}12,75 \\
(3,64)\end{array}$ & $\begin{array}{l}19,00 \\
(3,93)\end{array}$ & $\begin{array}{l}25,75 \\
(4,89)\end{array}$ \\
\hline saflufenacil $^{1}$ & 0,035 & $-0,75$ & $\begin{array}{c}1,75 \\
(1,44)\end{array}$ & $\begin{array}{c}4,00 \\
(1,99)\end{array}$ & $\begin{array}{l}33,50 \\
(5,77)\end{array}$ & $\begin{array}{l}12,75 \\
(3,62)\end{array}$ & $\begin{array}{l}26,25 \\
(5,15)\end{array}$ & $\begin{array}{l}14,50 \\
(3,85)\end{array}$ & $\begin{array}{l}23,25 \\
(4,75)\end{array}$ & $\begin{array}{l}82,75 \\
(8,88)\end{array}$ \\
\hline saflufenacil ${ }^{1}$ & 0,07 & $-1,00$ & $\begin{array}{c}2,00 \\
(1,52)\end{array}$ & $\begin{array}{c}4,50 \\
(2,22)\end{array}$ & $\begin{array}{l}34,25 \\
(5,89)\end{array}$ & $\begin{array}{l}11,25 \\
(3,31)\end{array}$ & $\begin{array}{l}20,50 \\
(4,49)\end{array}$ & $\begin{array}{c}8,50 \\
(2,99)\end{array}$ & $\begin{array}{l}19,00 \\
(4,05)\end{array}$ & $\begin{array}{l}48,50 \\
(6,55)\end{array}$ \\
\hline saflufenacil $^{1}$ & 0,105 & $-2,00$ & $\begin{array}{c}3,25 \\
(1,80)\end{array}$ & $\begin{array}{c}7,00 \\
(2,60)\end{array}$ & $\begin{array}{l}30,75 \\
(5,58)\end{array}$ & $\begin{array}{c}8,00 \\
(2,86)\end{array}$ & $\begin{array}{l}17,00 \\
(4,11)\end{array}$ & $\begin{array}{c}8,50 \\
(2,96)\end{array}$ & $\begin{array}{l}14,25 \\
(3,74)\end{array}$ & $\begin{array}{l}33,25 \\
(5,66)\end{array}$ \\
\hline saflu. + gly. ${ }^{1}$ & $0,035+2,160$ & $-1,75$ & $\begin{array}{c}1,00 \\
(1,18)\end{array}$ & $\begin{array}{c}8,00 \\
(2,89)\end{array}$ & $\begin{array}{l}22,00 \\
(4,74)\end{array}$ & $\begin{array}{l}15,75 \\
(4,02)\end{array}$ & $\begin{array}{l}32,00 \\
(5,68)\end{array}$ & $\begin{array}{l}16,25 \\
(4,08)\end{array}$ & $\begin{array}{l}16,75 \\
(3,86)\end{array}$ & $\begin{array}{l}73,75 \\
(7,47)\end{array}$ \\
\hline saflu. + gly. ${ }^{1}$ & $0,07+2,160$ & $-1,50$ & $\begin{array}{c}3,50 \\
(1,90)\end{array}$ & $\begin{array}{c}7,25 \\
(2,77)\end{array}$ & $\begin{array}{l}39,00 \\
(6,26)\end{array}$ & $\begin{array}{l}13,50 \\
(3,70)\end{array}$ & $\begin{array}{l}27,50 \\
(5,21)\end{array}$ & $\begin{array}{l}14,00 \\
(3,76)\end{array}$ & $\begin{array}{l}41,25 \\
(6,35)\end{array}$ & $\begin{array}{l}57,00 \\
(7,54)\end{array}$ \\
\hline saflu. + gly. ${ }^{1}$ & $0,105+2,160$ & 0,75 & $\begin{array}{c}4,25 \\
(2,03)\end{array}$ & $\begin{array}{l}11,00 \\
(3,32)\end{array}$ & $\begin{array}{l}29,00 \\
(5,40)\end{array}$ & $\begin{array}{l}13,50 \\
(3,67)\end{array}$ & $\begin{array}{l}27,25 \\
(5,17)\end{array}$ & $\begin{array}{l}11,25 \\
(3,40)\end{array}$ & $\begin{array}{l}36,25 \\
(5,79)\end{array}$ & $\begin{array}{l}48,50 \\
(6,98)\end{array}$ \\
\hline glyphosate & $\begin{array}{l}2,16 \\
---\end{array}$ & $\begin{array}{l}-1,25 \\
-\end{array}$ & $\begin{array}{c}3,50 \\
-(1,96)\end{array}$ & $\begin{array}{c}5,25 \\
(2,22)\end{array}$ & $\begin{array}{r}30,75 \\
(5,52) \\
-\end{array}$ & $\begin{array}{l}13,50 \\
(3,63)\end{array}$ & $\begin{array}{l}28,25 \\
(5,21)\end{array}$ & $\begin{array}{l}14,50 \\
(3,77)\end{array}$ & $\begin{array}{l}25,00 \\
(4,09)\end{array}$ & $\begin{array}{r}35,25 \\
-(5,90) .\end{array}$ \\
\hline $\mathrm{F}_{\text {TREATMENT }}$ & & -- & $1,342^{\mathrm{ns}}$ & $1,704^{\mathrm{ns}}$ & $2,012^{\text {ns }}$ & $0,884^{\text {ns }}$ & $1,090^{\text {ns }}$ & $1,990^{\text {ns }}$ & $0,930^{\text {ns }}$ & $1,092^{\mathrm{ns}}$ \\
\hline C.V. $(\%)$ & & -- & 40,7 & 27,8 & 12,8 & 20,5 & 18,9 & 16,3 & 44,7 & 35,9 \\
\hline d.m.s. & & -- & 0,37 & 1,73 & 1,7 & 0,36 & 2,2 & 1,35 & 4,79 & 5,66 \\
\hline
\end{tabular}

The data processed according to the equation $\mathrm{y}=(\mathrm{x}+0.5)^{\wedge} 2$ are shown within parentheses. ${ }^{1}$ The adjuvant Dash was added at $0.5 \% \mathrm{v} \mathrm{v}^{-1} ;{ }^{2}$ a.i. $=$ active ingredient; e.a. $=$ acid equivalent; ${ }^{3}$ second application; ${ }^{4}$ third application; DAA $=$ days after first application; saflu. $=$ Saflufenacil; gly. $=$ Glyphosate; ${ }^{\text {ns }}=$ not significant 
Souza et al. (2005) observed an improvement in the glyphosate (potassium salt) performance when combined with the butafenacil herbicide, which is also an protox inhibitor herbicide as the saflufenacil, on controlling Commelina benghalensis L. in a coffee crop.

The increase in the leaf number of the coffee plants in the evaluations performed after the successive sprayings, 90 and 180 DAA, did not changed by the saflufenacil applied singly or in combination with glyphosate at the rates used in this study (Table 4).

Weed management in coffee plantations are performed using directed spraying on the plant rows, however, application of non-selective herbicides with inadequate conditions of spraying pressure, boom height, operation speed and wind at the spraying time can cause problems related to the drift, causing visual phytotoxicity and prolonged and irreversible physiological damage to the coffee crop growth (FRANÇA et al., 2010a; FRANÇA et al., 2010b; CARVALHO et al., 2013; CARVALHO et

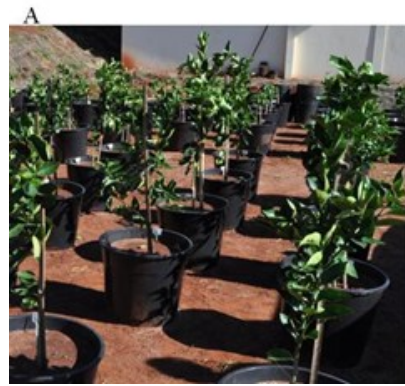

Figure 3. Valencia orange plants 90 days after the first application of the chemical treatments (A) and after 195 days (B) at the end of the experimental period. Botucatu, SP, 2012/13.

The increase in height of citrus plants 15 DAA was considered low or zero regardless of the chemical treatment analyzed, as well as the control without application of herbicides (Table 5). These results also indicated that the seedlings were still adapting to the new conditions in the pots. The following evaluations, at 30, 60 and 90 DAA, showed that the directed spraying of saflufenacil, applied singly and in combination with glyphosate, did not had any negative effects on plant growth at the rates studied (Table 5).

The evaluations after the sequential application, performed at 105, 120 and 150 DAA, also showed no negative effect on the plant height of citrus plants (Table 5). However, 180 DAA, a fast growth was observed in plants that received the application of saflufenacil combined with glyphosate

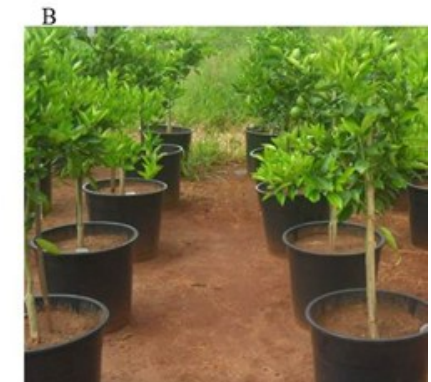

al., 2014; SCHRÜBBERS et al., 2014).

In the second experiment, visual phytotoxicity evaluations in citrus plants (Valencia) were also performed throughout the study. Similar to the results of coffee plants, the saflufenacil, applied singly and in combination with glyphosate at the rates studied, were visually selective (data not shown, because all phytotoxicity scores were equal to zero) (Figure 3A; 3B).

These results corroborate those found by Singh et al. (2011), who evaluated the selectivity of saflufenacil combined with glyphosate in single and sequential application on citrus plants, and found that the combination of these herbicides was selective, with no phytotoxicity symptoms in the citrus plants. Durigan et al. (2006) also reported selectivity of the flumioxazin, herbicide that is also inhibitor of the protox enzyme as the saflufenacil, applied singly and in combination with glyphosate, in citrus, with no visual symptoms in the citrus plants.

$\left(0,07+2,160\right.$ e $0,105+2,160 \mathrm{Kg}$ a.i./a.e. ha $^{-1}$, respectively) and the glyphosate applied singly $\left(2,160 \mathrm{Kg}\right.$ a.e. $\left.\mathrm{ha}^{-1}\right)$ (Table 5).

The treatments with saflufenacil combined with glyphosate $(0,07+2,160$ e $0,105+2,160 \mathrm{Kg}$ a.i./a.e. $\mathrm{ha}^{-1}$, respectively), also showed greater increase in height of citrus plants in the third sequential spraying, 180 DAA (Table 5).

Gravena et al. (2009) evaluating possible effects of non-lethal rates of glyphosate in citrus seedlings caused by drift or accidental spraying, observed transient effects on the shikimate and total free amino acids contents in lemon seedlings, even in the absence of visual phytotoxicity symptoms, however, these plants presented fast recovery after the treatment with glyphosate. 
Table 5. Increase in height $(\mathrm{cm})$ of Valencia orange plants submitted to different herbicide applications. Botucatu / SP, 2012/13.

\begin{tabular}{|c|c|c|c|c|c|c|c|c|c|c|}
\hline \multirow{2}{*}{ Treatments } & \multirow{2}{*}{$\begin{array}{c}\text { Rate } \\
\text { a.i./a.e. } \\
(\text { Kg ha-1 })^{2}\end{array}$} & \multicolumn{9}{|c|}{ Evaluations } \\
\hline & & $\begin{array}{c}15 \\
\text { DAA }\end{array}$ & $\begin{array}{c}30 \\
\text { DAA }\end{array}$ & $\begin{array}{c}60 \\
\text { DAA }\end{array}$ & $\begin{array}{c}90 \\
\mathrm{DAA}^{3}\end{array}$ & $\begin{array}{c}105 \\
\text { DAA }\end{array}$ & $\begin{array}{c}120 \\
\text { DAA }\end{array}$ & $\begin{array}{c}150 \\
\text { DAA }\end{array}$ & $\begin{array}{c}180 \\
\text { DAA }^{4}\end{array}$ & $\begin{array}{c}195 \\
\text { DAA }\end{array}$ \\
\hline Control & -- & 0 & $\begin{array}{c}1,25 \\
(1,27)\end{array}$ & $\begin{array}{c}2,00 \\
(1,50)\end{array}$ & $\begin{array}{l}17,00 \\
(4,18)\end{array}$ & $\begin{array}{c}3,25 \\
(1,81)\end{array}$ & $\begin{array}{c}1,75 \\
(1,49)\end{array}$ & $\begin{array}{c}3,25 \\
(1,81)\end{array}$ & $\begin{array}{c}5,00 \\
(2,28) \mathrm{CD}\end{array}$ & $\begin{array}{c}3,75 \\
(2,03) \mathrm{C}\end{array}$ \\
\hline saflufenacil $1^{1}$ & 0,035 & 0,50 & $\begin{array}{c}1,50 \\
(1,40)\end{array}$ & $\begin{array}{c}1,00 \\
(1,15)\end{array}$ & $\begin{array}{l}18,75 \\
(4,09)\end{array}$ & $\begin{array}{c}5,25 \\
(2,14)\end{array}$ & $\begin{array}{c}2,50 \\
(1,52)\end{array}$ & $\begin{array}{c}5,25 \\
(2,14)\end{array}$ & $\begin{array}{c}3,75 \\
(1,85) \mathrm{D}\end{array}$ & $\begin{array}{c}2,75 \\
(1,65) \mathrm{C}\end{array}$ \\
\hline saflufenacil $1^{1}$ & 0,07 & 0,25 & $\begin{array}{c}0,50 \\
(0,97)\end{array}$ & $\begin{array}{c}1,75 \\
(1,30)\end{array}$ & $\begin{array}{l}11,00 \\
(3,35)\end{array}$ & $\begin{array}{c}4,75 \\
(2,26)\end{array}$ & $\begin{array}{c}1,75 \\
(1,45)\end{array}$ & $\begin{array}{c}4,75 \\
(2,26)\end{array}$ & $\begin{array}{c}1,00 \\
(1,44) \mathrm{D}\end{array}$ & $\begin{array}{c}0,25 \\
(2,60) \mathrm{C}\end{array}$ \\
\hline saflufenacil $1^{1}$ & 0,105 & 0,25 & $\begin{array}{c}0,75 \\
(1,06)\end{array}$ & $\begin{array}{c}3,25 \\
(1,67)\end{array}$ & $\begin{array}{r}5,50 \\
(2,41)\end{array}$ & $\begin{array}{c}3,25 \\
(1,84)\end{array}$ & $\begin{array}{l}1,00 \\
(1,15)\end{array}$ & $\begin{array}{c}3,00 \\
(1,71)\end{array}$ & $\begin{array}{c}8,25 \\
(2,81) \mathrm{BCD}\end{array}$ & $\begin{array}{c}5,25 \\
(2,23) \mathrm{C}\end{array}$ \\
\hline saflu. + gly. ${ }^{1}$ & $0,035+2,160$ & 0,25 & $\begin{array}{c}0,25 \\
(0,84)\end{array}$ & $\begin{array}{c}1,50 \\
(1,17)\end{array}$ & $\begin{array}{l}15,00 \\
(3,79)\end{array}$ & $\begin{array}{c}2,00 \\
(1,48)\end{array}$ & $\begin{array}{c}1,00 \\
(1,15)\end{array}$ & $\begin{array}{c}2,00 \\
(1,48)\end{array}$ & $\begin{array}{c}4,25 \\
(2,13) \mathrm{CD}\end{array}$ & $\begin{array}{c}3,00 \\
(1,82) \mathrm{C}\end{array}$ \\
\hline saflu. + gly. ${ }^{1}$ & $0,07+2,160$ & 0 & $\begin{array}{c}0,25 \\
(0,84)\end{array}$ & $\begin{array}{c}1,50 \\
(1,17)\end{array}$ & $\begin{array}{l}19,50 \\
(4,41)\end{array}$ & $\begin{array}{c}5,00 \\
(2,06)\end{array}$ & $\begin{array}{c}0,75 \\
(1,00)\end{array}$ & $\begin{array}{c}4,00 \\
(1,91)\end{array}$ & $\begin{array}{c}41,25 \\
(5,73) \mathrm{AB}\end{array}$ & $\begin{array}{c}63,75 \\
(7,57) \mathrm{A}\end{array}$ \\
\hline saflu. + gly. ${ }^{1}$ & $0,105+2,160$ & 0,25 & $\begin{array}{c}1,00 \\
(1,18)\end{array}$ & $\begin{array}{c}0,75 \\
(1,00)\end{array}$ & $\begin{array}{l}15,00 \\
(3,88)\end{array}$ & $\begin{array}{c}2,00 \\
(1,26)\end{array}$ & $\begin{array}{c}1,75 \\
(1,38)\end{array}$ & $\begin{array}{c}2,00 \\
(1,26)\end{array}$ & $\begin{array}{c}48,00 \\
(6,87) \mathrm{A}\end{array}$ & $\begin{array}{c}32,00 \\
(5,62) \mathrm{AB}\end{array}$ \\
\hline glyphosate & 2,16 & $\begin{array}{c}0,25 \\
-\end{array}$ & $\begin{array}{c}1,50 \\
(0,97)\end{array}$ & $\begin{array}{c}2,25 \\
-(1,47)\end{array}$ & $\begin{array}{l}11,50 \\
(3,79)\end{array}$ & $\begin{array}{c}6,75 \\
-(2,48)\end{array}$ & $\begin{array}{c}3,25 \\
(1,83) \\
-\end{array}$ & $\begin{array}{c}7,00 \\
-(2,52) \\
-\end{array}$ & $\begin{array}{c}29,25 \\
(5,44) \mathrm{ABC}\end{array}$ & $\begin{array}{c}19,75 \\
(4,49) \text { BC }\end{array}$ \\
\hline $\mathrm{F}_{\text {TREATMENT }}$ & & - & $1,623^{\mathrm{ns}}$ & $0,284^{\mathrm{ns}}$ & $1,399^{\mathrm{ns}}$ & $0,672^{\mathrm{ns}}$ & $0,737^{\mathrm{ns}}$ & $0,730^{\mathrm{ns}}$ & $8,259 * *$ & $11,744 * *$ \\
\hline C.V. $(\%)$ & & -- & 30,2 & 63,8 & 30,1 & 51,3 & 45 & 51,3 & 40,9 & 36,1 \\
\hline d.m.s. & & -- & 0,16 & 1,94 & 2,58 & 2,3 & 1,44 & 2,26 & 3,42 & 2,96 \\
\hline
\end{tabular}

Means followed by the same uppercase letter in the column did not differ statistically by the Tukey test ( $>>0.05)$. The data processed according to the equation $\mathrm{y}=(\mathrm{x}+0.5)^{\wedge} 2$ are shown within parentheses. ${ }^{1}$ The adjuvant Dash was added at $0.5 \% \mathrm{v} \mathrm{v}^{-1} ;{ }^{2}$ a.i. $=$ active ingredient; e.a. $=$ acid equivalent; ${ }^{3}$ second application; ${ }^{4}$ third application; DAA $=$ days after first application; saflu. $=$ Saflufenacil; gly. $=$ Glyphosate $*$ Significant at $5 \%$ probability; ${ }^{\mathrm{ns}}=$ not significant.

A low increase in the number of leaves in orange plants in the first evaluation 15 DAA (Table 6) was observed, also due to the adaptation process of plants to the new conditions in the pots. The plants submitted to saflufenacil treatments $(0.07$ and $0.105 \mathrm{~kg}$ a.i. ha $\left.{ }^{-1}\right)$ had a small defoliation compared to the other treatments (Table 6). However, no correlation between the defoliation and the saflufenacil application was found, since there were no significant differences between the chemical treatments and the control in the following evaluations, performed 30, 60 and 90 DAA.

The increase in number of leaves in the treated orange plants was similar or higher than those found in the control from the second evaluation (30 DAA) and by the end of the study (195 DAA). The two sequential applications of chemical treatments, performed 90 and 180 DAA, provided no negative effects on this variable (Table 6).

Singh et al. (2011) reported that the saflufenacil combined with glyphosate presented greater efficacy in weed control compared to these herbicides applied singly in citrus areas, and they are selective to this crop. Other studies also reported satisfactory effect of the glyphosate combined with saflufenacil in weeds that are difficult to control and/ or resistant to glyphosate (MARTINS et al., 2012; EUBANK et al., 2013).

Overall, the present study confirms that saflufenacil combined with glyphosate may be a viable alternative to ensure the success in controlling broadleaf and grass weeds on agricultural areas with coffee and citrus without any damage to these crops, and may reduce the effects of a possible tolerance of weeds to glyphosate. 
Table 6. Increase in leaf number of Valencia orange plants submitted to different herbicide applications. Botucatu / SP, 2012/13.

\begin{tabular}{|c|c|c|c|c|c|c|c|c|c|c|}
\hline \multirow{2}{*}{ Treatments } & \multirow{2}{*}{$\begin{array}{c}\text { Rate } \\
\text { a.i./a.e. } \\
\left(\mathrm{Kg} \mathrm{ha}^{-1}\right)^{2}\end{array}$} & \multicolumn{9}{|c|}{ Evaluations } \\
\hline & & $\begin{array}{c}15 \\
A A\end{array}$ & $\begin{array}{c}30 \\
\text { DAA }\end{array}$ & $\begin{array}{c}60 \\
A A\end{array}$ & $\begin{array}{c}90 \\
\mathrm{DAA}^{3}\end{array}$ & 105 & $\begin{array}{c}120 \\
\text { DAA }\end{array}$ & $\begin{array}{l}150 \\
D A A\end{array}$ & $\begin{array}{c}180 \\
\mathrm{DAA}^{4}\end{array}$ & $\begin{array}{c}195 \\
\text { DAA }\end{array}$ \\
\hline \multirow[b]{2}{*}{ Control } & \multirow[b]{2}{*}{--} & \multirow[b]{2}{*}{1,5} & 0,75 & 29.00 & 47.50 & 23,75 & 11,25 & 23,25 & 58,25 & 51.75 \\
\hline & & & $(1,06)$ & $(5,08)$ & $(6,42)$ & $(4,47) \mathrm{AB}$ & $(3,07)$ & $(4,39)$ & $(7,36) \mathrm{AB}$ & $(7,17)$ \\
\hline \multirow{2}{*}{ saflufenacil $^{1}$} & \multirow{2}{*}{0,035} & \multirow{2}{*}{1} & 0,25 & 41,00 & 43,75 & 27,00 & 13,75 & 27,00 & 29,75 & 12,25 \\
\hline & & & $(0,84)$ & $(5,97)$ & $(6,29)$ & $(4,92) \mathrm{AB}$ & $(3,57)$ & $(4,92)$ & $(4,35) \mathrm{B}$ & $(2,81)$ \\
\hline \multirow{2}{*}{ saflufenacil $^{1}$} & \multirow{2}{*}{0,07} & \multirow{2}{*}{$-2,75$} & 0,00 & 26,50 & 102,50 & 24,75 & 12,75 & 24,75 & 193,50 & 75,75 \\
\hline & & & $(0,71)$ & $(4,78)$ & $(9,29)$ & $(4,58) \mathrm{AB}$ & $(3,39)$ & $(4,58)$ & $(13,73) \mathrm{A}$ & $(8,60)$ \\
\hline \multirow{2}{*}{ saflufenacil $^{1}$} & \multirow{2}{*}{0,105} & \multirow{2}{*}{$-1,25$} & 0,25 & 37,00 & 36,50 & 47,75 & 26,75 & 45,75 & 68,00 & 44,75 \\
\hline & & & $(0,84)$ & $(6,11)$ & $(5,44)$ & $(6,59) \mathrm{A}$ & $(5,11)$ & $(6,28)$ & $(7,23) \mathrm{AB}$ & $(5,30)$ \\
\hline saflu. + gly. ${ }^{1}$ & \multirow[t]{2}{*}{$0,035+2,160$} & \multirow{2}{*}{0,5} & 0,50 & $\begin{array}{l}38,75 \\
(5,79)\end{array}$ & 58,25 & 36,00 & 16,25 & 32,50 & 154,75 & 1,25 \\
\hline \multirow[b]{2}{*}{ saflu. + gly. ${ }^{1}$} & & & $(0,9$ & ) & 86 & $(5,85$ & $3,74)$ & $(5,23)$ & & $\begin{array}{l}(1,35) \\
4475\end{array}$ \\
\hline & $0,07+2,160$ & 3,25 & $\begin{array}{c}0,25 \\
(0,84)\end{array}$ & $\begin{array}{l}68,75 \\
(7,74)\end{array}$ & $\begin{array}{l}54,25 \\
(6,99)\end{array}$ & $\begin{array}{c}44,25 \\
(6,11) \mathrm{AB}\end{array}$ & $\begin{array}{l}19,75 \\
(3,77)\end{array}$ & $\begin{array}{l}42,25 \\
(5,84)\end{array}$ & $\begin{array}{c}92,75 \\
(8,77) \mathrm{AB}\end{array}$ & $\begin{array}{l}44,75 \\
(5,09)\end{array}$ \\
\hline \multirow{2}{*}{ saflu. + gly. ${ }^{1}$} & \multirow{2}{*}{$0,105+2,160$} & \multirow{2}{*}{5,75} & 0,25 & 24,75 & 89,00 & 1,25 & 0,75 & 3,50 & 147,75 & 168,75 \\
\hline & & & $(0,84)$ & $(4,41)$ & $(9,11)$ & $(1,21) \mathrm{B}$ & $(2,05)$ & $(1,88)$ & $(11,61) \mathrm{AB}$ & $(11,07)$ \\
\hline \multirow{2}{*}{$\begin{array}{l}\text { glyphosate } \\
-\ldots-\ldots--\end{array}$} & \multirow{2}{*}{2,16} & \multirow{2}{*}{3,25} & 0,25 & 31,00 & 59,50 & 11,75 & 7,25 & 11,50 & 54,25 & 66,75 \\
\hline & & & $-(0,84)$ & $(5,09)$ & $(7,28)$ & $(2,87)$ AB & $(2,53)$ & _ $(2,74)$. & $(6,95)$ AB & $(6,31)$ \\
\hline \multicolumn{2}{|l|}{$\mathrm{F}_{\text {TREATMENT }}$} & -- & $0,445^{\mathrm{ns}}$ & $0,664^{\mathrm{ns}}$ & $0,660^{\mathrm{ns}}$ & $2,488^{*}$ & $1,183^{\mathrm{ns}}$ & $1,398^{\mathrm{ns}}$ & $3,149^{*}$ & $2,358^{\mathrm{ns}}$ \\
\hline \multicolumn{2}{|l|}{ C.V. $(\%)$} & -- & 34,3 & 46,2 & 45,8 & 49,5 & 49,5 & 56,4 & 39,9 & 71,7 \\
\hline \multicolumn{2}{|l|}{ d.m.s. } & -- & 0,69 & 6,09 & 1,65 & 5,31 & 3,95 & 5,92 & 8,54 & 9,88 \\
\hline
\end{tabular}

Means followed by the same uppercase letter in the column did not differ statistically by the Tukey test ( $p>0.05)$. The data processed according to the equation $\mathrm{y}=(\mathrm{x}+0.5)^{\wedge} 2$ are shown within parentheses. ${ }^{1}$ The adjuvant Dash was added at $0.5 \% \mathrm{v} \mathrm{v}^{-1} ;{ }^{2}$ a.i. $=$ active ingredient; e.a. $=$ acid equivalent; ${ }^{3}$ second application; ${ }^{4}$ third application; DAA $=$ days after first application; saflu. $=$ Saflufenacil; gly. $=$ Glyphosate; ${ }^{*}$ Significant at $5 \%$ probability; ${ }^{\text {ns }}=$ not significant.

\section{CONCLUSIONS}

The saflufenacil herbicide applied singly and in combination with glyphosate, with directed spraying, was selective to coffee and citrus plants, causing no visual phytotoxicity symptoms in the plants.

The sequential saflufenacil spraying, applied singly and in combination with glyphosate, with directed spraying in a sandy soil did not affect the initial growth of coffee and citrus plants.

The saflufenacil has potential for use in combination with glyphosate to provide control of many weed species in coffee and citrus areas without any interference in the development of these species.

\section{REFERENCES}

ASHIGH, J.; HALL, J. C. Bases for interactions between saflufenacil and glyphosate in plants. Journal of agricultural and food chemistry, Easton, v. 58, n. 12, p. 7335-7343, 2010.

CARVALHO, F. P. D. et al. Photosynthetic activity of coffee after application of glyphosate subdoses. Acta Scientiarum, Maringá, v. 35, n. 1, p. 109-115, 2013.

CARVALHO, F. P. D. et al. Water use efficiency by coffee arabica after glyphosate application. Acta Scientiarum, Maringá, v. 36, n. 3, p. 373-377, 2014.

CHEAH, U. B.; KIRKWOOD, R. C.; LUM, K. Y. Adsorption, desorption and mobility of four commonly used pesticides in Malaysian agricultural soils. Pesticide Science, Oxford, v. 50, n. 1, p. 53 63, 1997.

DURIGAN, J. C. et al. Eficácia doflumioxazin, aplicado isolado e em mistura com Glyphosate, para o controle de plantas daninhas em citros. Revista Brasileira de Herbicidas, Maringá, v. 5, n. 2, p. 45 56, 2006.

EUBANK, T. W. et al. Saflufenacil efficacy on horseweed and its interaction with glyphosate. Weed Biology and Management, Malden, v. 13, n. 4, p. 135-143, 2013.

FILIZOLA, H. F. et al. Monitoramento e avaliação do risco de contaminação por pesticidas em água superficial e subterrânea na região de Guaíra. Pesquisa Agropecuária Brasileira, Brasília, v. 37, n. 5, p. 659-667, 2002.

FRANÇA, A. C. et al. Crescimento de cultivares de café arábica submetidos a doses do glyphosate. Planta Daninha,Viçosa, v. 28, n. 3, p. 599-607, 2010a. 
FRANÇA, A. et al. Teores de nutrientes em cultivares de café arábica submetidos à deriva de glyphosate. Planta Daninha,Viçosa, v. 28, n. 4, p. $877-885,2010$ b.

GRAVENA, R. et al. Low glyphosate rates do not affect Citrus limonia (L.) Osbeck seedlings. Pest Management Science, Sussex, v. 65, n. 4, p. 420$425,2009$.

GROSSMANN, K. et al. The herbicide saflufenacil (Kixor ${ }^{\mathrm{TM}}$ ) is a new inhibitor of protoporphyrinogen IX oxidase activity. Weed Science, Champaign, v. 58, n. 1, p. 1-9, 2010.

GROSSMANN, K. et al. Saflufenacil (Kixor ${ }^{\mathrm{TM}}$ ): biokinetic properties and mechanism of selectivity of a new protoporphyrinogen IX oxidase inhibiting herbicide.Weed Science, Champaign, v. 59, n. 3, p. 290-298, 2011.

MARTINS, D. et al. Manejo químico de espécies de trapoeraba com aplicação isolada e em mistura de diferentes herbicidas. Revista Caatinga, Mossoró, v. 25, n. 2, p. 21-28, 2012.

MATALLO, M. B. et al. Sorption and desorption of saflufenacil in two soils in the state of São Paulo with different physical and chemical attributes. Planta Daninha, Viçosa, v. 32, n. 2, p. 393-399, 2014.

MONQUERO, P. A. et al. Lixiviação de saflufenacil e residual após períodos de seca. Planta Daninha,Viçosa, v. 30, n. 2, p. 415-423, 2012.

MOREIRA, M. S. et al. Resistência de Conyzacanadensis e $C$. bonariensis ao herbicida glyphosate. Planta Daninha,Viçosa, v. 25, n. 1, p. 157-164, 2007.

OWEN, M. D. K. Weed species shifts in glyphosate resistant crops. Pest Management Science, Sussex, v. 64 , n. 4 , p. $377-387,2008$.

PAPIERNIK, S. K.; KOSKINEN, W. C.; BARBER, B. L. Low sorption and fast dissipation of the herbicide saflufenacil in surface soils and subsoils of an eroded prairie landscape. Journal of agricultural and food chemistry, Easton, v. 60, n. 44, p. 10936 10941, 2012.

POWLES, S. B. Evolved glyphosate resistant weeds around the world: lessons to be learnt. Pest Management Science, Sussex, v. 64, n. 4, p. 360365, 2008.

RAIJ, B.V et al. Recomendações de adubação e calagem para o Estado de São Paulo. 2. ed. Campinas: IAC, 1996. 285 p. (IAC. Boletim
Técnico, 100).

SCHRÜBBERS, L. C. et al. Glyphosate spray drift in Coffea arabica - Sensitivity of coffee plants and possible use of shikimic acid as a biomarker for glyphosate exposure. Pesticide Biochemistry and Physiology, San Diego, v. 115, n. 1, p. 15-22, 2014.

SILVA, K. C. et al. Tolerância de mamoneira ao herbicida pendimethalin em solos com diferentes capacidades de adsorção. Revista Brasileira de Engenharia Agrícola e Ambiental, Campina Grande, v. 16, n. 12, p. 1298-1304, 2012.

SINGH, M. et al. Tank mix of saflufenacil with glyphosate and pendimethalin for broad-spectrum weed control in Florida citrus. HortTechnology, Alexandria, v. 21, n. 5, p. 606-615, 2011.

SOUZA, L. S. et al. Eficácia do glifosato potássico em mistura com butafenacil no controle detrapoeraba na cultura do café. Revista Brasileira de Herbicidas, Maringá, v. 4, n. 1, p. 112-119, 2005.

YAMAUTI, M. S. et al. Controle químico de biótipos de buva (Conyzacanadensis e Conyzabonariensis) resistentes ao glyphosate. Revista Ciência Agronômica, Fortaleza, v. 41, n. 3, p. 495-500, 2010.

ZAMBON, S.; FOLONI, L. L.; SOUZA, E. L. C. Avaliação do saflufenacil isolado e combinado com glyphosate no controle da vegetação infestante nas ruas da cultura do café. In: CONGRESSO DA ASOCIACION LATINOAMERICANA DE MALEZAS, 19., 2009, Lisboa. Anais... Lisboa: UTL, 2009. p. 769-772. 